\title{
Front Matter: Volume 6799
}

, "Front Matter: Volume 6799," Proc. SPIE 6799, BioMEMS and

Nanotechnology III, 679901 (8 February 2008); doi: 10.1117/12.786725

EDIE Event: SPIE Microelectronics, MEMS, and Nanotechnology, 2007, Canberra, ACT, Australia 


\section{PROGRESS IN BIOMEDICAL OPTICS AND IMAGING}

Vol. 8, No. 50

\section{BioMEMS and Nanotechnology III}

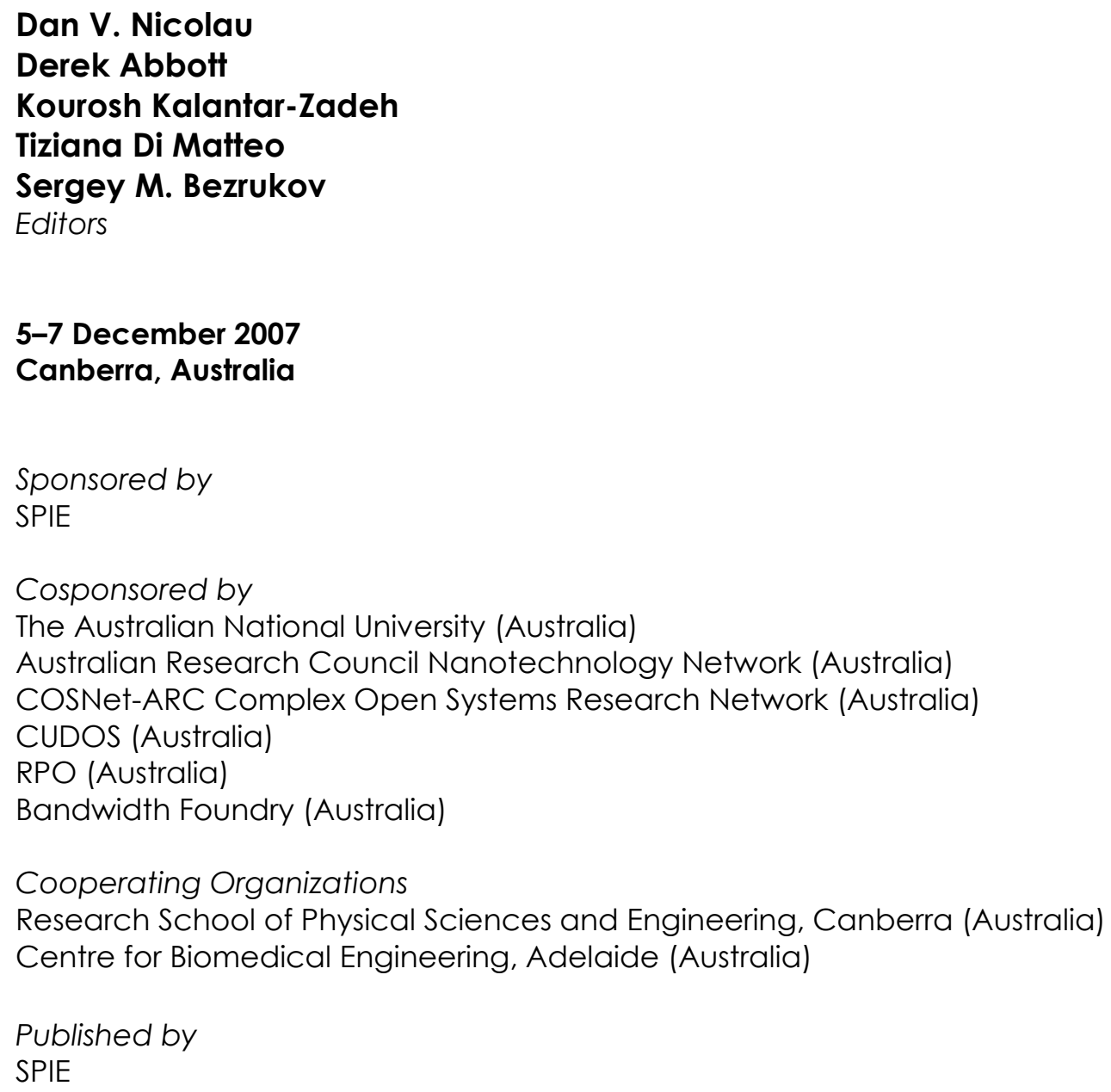

Volume 6799 
The papers included in this volume were part of the technical conference cited on the cover and title page. Papers were selected and subject to review by the editors and conference program committee. Some conference presentations may not be available for publication. The papers published in these proceedings reflect the work and thoughts of the authors and are published herein as submitted. The publisher is not responsible for the validity of the information or for any outcomes resulting from reliance thereon.

Please use the following format to cite material from this book:

Author(s), "Title of Paper," in BioMEMS and Nanotechnology III, edited by Dan V. Nicolau, Derek Abbott, Kourosh Kalantar-Zadeh, Tiziana Di Matteo, Sergey M. Bezrukov, Proceedings of SPIE Vol. 6799 (SPIE, Bellingham, WA, 2007) Article CID Number.

ISSN 1605-7422

ISBN 9780819469700

Published by

SPIE

P.O. Box 10, Bellingham, Washington 98227-0010 USA

Telephone +1 3606763290 (Pacific Time) · Fax +1 3606471445

SPIE.org

Copyright (C) 2008, Society of Photo-Optical Instrumentation Engineers.

Copying of material in this book for internal or personal use, or for the internal or personal use of specific clients, beyond the fair use provisions granted by the U.S. Copyright Law is authorized by SPIE subject to payment of copying fees. The Transactional Reporting Service base fee for this volume is $\$ 18.00$ per article (or portion thereof), which should be paid directly to the Copyright Clearance Center (CCC), 222 Rosewood Drive, Danvers, MA 01923. Payment may also be made electronically through CCC Online at copyright.com. Other copying for republication, resale, advertising or promotion, or any form of systematic or multiple reproduction of any material in this book is prohibited except with permission in writing from the publisher. The CCC fee code is 1605 $7422 / 08 / \$ 18.00$.

Printed in the United States of America.

Publication of record for individual papers is online in the SPIE Digital Library.

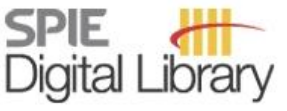

SPIEDigitallibrary.org

Paper Numbering: Proceedings of SPIE follow an e-First publication model, with papers published first online and then in print and on CD-ROM. Papers are published as they are submitted and meet publication criteria. A unique, consistent, permanent citation identifier (CID) number is assigned to each article at the time of the first publication. Utilization of CIDs allows articles to be fully citable as soon they are published online, and connects the same identifier to all online, print, and electronic versions of the publication. SPIE uses a six-digit CID article numbering system in which:

- The first four digits correspond to the SPIE volume number.

- The last two digits indicate publication order within the volume using a Base 36 numbering system employing both numerals and letters. These two-number sets start with 00, 01, 02, 03, 04, $05,06,07,08,09,0 \mathrm{~A}, 0 \mathrm{~B} \ldots \mathrm{.0Z}$, followed by 10-1Z, 20-2Z, etc.

The CID number appears on each page of the manuscript. The complete citation is used on the first page, and an abbreviated version on subsequent pages. Numbers in the index correspond to the last two digits of the six-digit CID number. 


\title{
Contents
}

\author{
ix Conference Committee \\ xiii Introduction \\ xV Symposium Sponsors
}

\section{SESSION 1 NANOSCALE INTERACTIONS AND DEVICES I}

679903 Atomic force microscopy study on the attachment of E. coli and S. aureus to a patterned surface of different materials [6799-02]

H. Zhang, A. Komaromy, R. I. Boysen, Monash Univ. (Australia); G. Rius, X. Borrise,

F. Perez-Murano, Ctr. Nacional de Microelectronica, CSIC (Spain); M. T. W. Hearn, Monash Univ. (Australia); D. V. Nicolau, Monash Univ. (Australia) and The Univ. of Liverpool (United Kingdom)

679904 The molecular adsorption-type endotoxin detection system using immobilized $\varepsilon$-polylysine [6799-03]

K. Ooe, A. Tsuji, Ritsumeikan Univ. (Japan); N. Nishishita, Y. Hirano, Osaka Institute of Technology (Japan)

679905 Analysis and feasibility of chemical recording using thermosensitive liposomes [6799-04] M. E. Tanner, Duke Univ. (USA); E. A. Vasievich, Univ. of North Carolina (USA); J. M. Protz, Duke Univ. (USA)

\section{SESSION $2 \quad$ NANOSCALE INTERACTIONS AND DEVICES II}

679906 DNA-conjugated metal nanoparticle for bioanalytics, nanophotonics, and nanoelectronics (Invited Paper) [6799-05]

W. Fritzsche, A. Csaki, R. Möller, A. Steinbrück, G. Festag, A. Wolff, T. Schüler, Institute for Photonic Technology Jena (Germany)

679907 Interfacing porous silicon with biomolecules [6799-06]

M. J. Sweetman, S. D. Graney, N. H. Voelcker, Flinders Univ. (Australia)

679908 Porous silicon biosensor for the detection of auto-immune diseases [6799-07]

A. O. Jane, E. J. Szili, Flinders Univ. (Australia); J. H. Reed, T. P. Gordon, Flinders Medical Ctr. (Australia); N. H. Voelcker, Flinders Univ. (Australia)

679909 Control over wettability via surface modification of porous gradients [6799-08]

Y. L. Khung, Flinders Univ. (Australia); M. A. Cole, Univ. of South Australia (Australia);

S. J. P. Mclnnes, N. H. Voelcker, Flinders Univ. (Australia) 
6799 OB Spark plasma sintering of silver nanopowder [6799-10]

H. B. Ng, C. Shearwood, T. J. White, L. G. YU, K. A. Khor, Nanyang Technological Univ. (Singapore)

6799 OC Effects of surfactants on the formation of microdroplets in the flow focusing microfluidic device [6799-11]

N. WU, CSIRO Materials Science and Engineering (Australia) and Australian National Univ. (Australia); Y. Zhu, P. W. Leech, B. A. Sexton, CSIRO Materials Science and Engineering (Australia); S. Brown, CSIRO Entomology (Australia); C. Easton, Australian National Univ. (Australia)

6799 OD Mechanisms of formation of nanostructures with atomic force microscopy [6799-12] H. Lee, L. Peng, K. Wang, M. K. Yapici, J. Zou, H. Liang, Texas A\&M Univ. (USA)

$6799 \mathrm{OE}$ Influence of addition of larger particles into 3-nm particles of $\mathrm{TiO}_{2}$ film on the performance of dye-sensitized solar cells [6799-21]

H. Wang, J. Bell, Queensland Univ. of Technology (Australia)

6799 OF Superhydrophobic and superhydrophilic surfaces with $\mathrm{MoO}_{\mathrm{x}}$ submicron structures [6799-15] J. Campbell, M. Breedon, W. Wlodarski, K. Kalantar-zadeh, RMIT Univ. (Australia)

$6799 \mathrm{OH} \quad$ Surface acoustic wave device-based wireless passive microvalve for microfluidic applications [6799-17]

D. W. Dissanayake, S. F. Al-Sarawi, D. Abbott, Univ. of Adelaide (Australia)

\section{SESSION 4 BIOMEMS, BIOSENSORS, AND MICROFLUIDS I}

$6799 \mathrm{OJ}$ Effect of various artificial surfaces on the colonization and viability of $E$. coli and S. aureus [6799-20]

A. Komaromy, R. I. Boysen, H. Zhang, M. T. W. Hearn, Monash Univ. (Australia); D. V. Nicolau, Monash Univ. (Australia) and The Univ. of Liverpool (United Kingdom)

6799 OK Thermal analysis of cell electro-rotation chip [6799-22]

G. Xu, D. Lee, M. Vyshnavi, J. Y. Ying, Institute of Bioengineering and Nanotechnology (Singapore)

SESSION 5 BIOMEMS, BIOSENSORS, AND MICROFLUIDS II

6799 OL Biological applications of microscope profiler (Invited Paper) [6799-23]

S. Han, E. Novak, Veeco Instruments, Inc. (USA); J. Reed, M. Teitell, J. Gimzewski, Univ. of California, Los Angeles (USA)

6799 ON Development of a blood extraction device for a miniature SMBG system [6799-25] Y. Matsuura, Osaka Institute of Technology (Japan); T. Uenoya, ASTEM (Japan); K. Tsuchiya, Tokai Univ. (Japan); Y. Uetsuji, Osaka Institute of Technology (Japan); E. Nakamachi, Doshisha Univ. (Japan) 
679900 A systematic approach to fabricate high aspect ratio silicon micro-needles for transdermal drug delivery [6799-26]

H. B. Ng, C. Shearwood, Nanyang Technological Univ. (Singapore)

6799 OP Ultra-small volume interdigital sensors for the measurement of human breast milk [6799-27] A. Keating, W. W. Pang, C. T. Lai, P. Hartmann, The Univ. of Western Australia (Australia)

$67990 Q \quad$ Design of painless microneedle for blood extraction system [6799-28]

K. Tsuchiya, K. Isobata, M. Sato, Tokai Univ. (Japan); Y. Uetsuji, E. Nakamachi, Osaka Institute of Technology (Japan); K. Kajiwara, M. Kimura, Tokai Univ. (Japan)

6799 OS Low cost optical particle detection for lab-on-chip systems based on DVD technology [6799-31]

A. L. Clow, Univ. of Canterbury (New Zealand); R. Künnemeyer, Univ. of Waikato (New Zealand); P. Gaynor, Univ. of Canterbury (New Zealand); J. C. Sharpe, HortResearch Ruakura (New Zealand)

6799 OT Novel electromagnetic micropump [6799-32]

M. Feldmann, S. Demming, C. Lesche, S. Büttgenbach, Technical Univ. of Braunschweig (Germany)

6799 OU Induced movement of the magnetic beads and DNA-based dumbbell in a micro fluidic channel [6799-33]

B. Babić, R. Ghai, K. Dimitrov, The Univ. of Queensland (Australia)

SESSION 6 BIOMEMS, BIOSENSORS, AND MICROFLUIDS III

6799 OV Bioimprint replication of single cells on a biochip (Invited Paper) [6799-34]

M. M. Alkaisi, Univ. of Canterbury (New Zealand) and MacDiarmid Institute for Advanced Materials and Nanotechnology (New Zealand); J. J. Muys, Univ. of Canterbury (New Zealand), Univ. of Otago (New Zealand), and MacDiarmid Institute for Advanced Materials and Nanotechnology (New Zealand); J. J. Evans, Univ. of Otago (New Zealand) and MacDiarmid Institute for Advanced Materials and Nanotechnology (New Zealand)

6799 OW Preparation of two-directional gradient surfaces for the analysis of cell-surface interactions [6799-35]

L. R. Clements, Flinders Univ. (Australia), CSIRO Molecular and Health Technologies (Australia), and CSIRO Food Futures Flagship (Australia); Y.-L. Khung, Flinders Univ. (Australia); H. Thissen, CSIRO Molecular and Health Technologies (Australia) and CSIRO Food Futures Flagship (Australia); N. H. Voelcker, Flinders Univ. (Australia) and CSIRO Food Futures Flagship (Australia)

6799 OX Characterization of flows in micro contractions using micro-PIV and CFD to study the protein aggregation process [6799-36]

F. J. Tovar-Lopez, A. Mitchell, RMIT Univ. (Australia); G. Rosengarten, Univ. of New South Wales (Australia)

6799 OY Micro-patterning of polymer-based optical oxygen sensors for lab-on-chip applications [6799-37]

V. Nock, R. J. Blaikie, Univ. of Canterbury (New Zealand); T. David, MacDiarmid Institute for Advanced Materials and Nanotechnology (New Zealand) 
$6799 \mathrm{OZ}$ Microfluidic device for controlled dilution and sorting of droplets by electrokinetic driving forces [6799-38]

P. Carreras, S. Mohr, P. R. Fielden, N. J. Goddard, Univ. of Manchester (United Kingdom)

679910 Design and fabrication of polymer microfluidic chip for ESI-MS [6799-39]

S. Malahat, P. Iovenitti, I. Sbarski, Swinburne Univ. of Technology (Australia)

\section{SESSION 8 MODELLING AND THZ TECHNOLOGY}

$679911 \quad$ Neural network prediction of protein adsorption [6799-40]

D. V. Nicolau, Jr., Univ. of Oxford (United Kingdom); E. Vasina, E. Paszek, D. V. Nicolau, The Univ. of Liverpool (United Kingdom)

679913 Signal compression in biological sensory systems: information theoretic performance limits [6799-42]

M. D. McDonnell, Univ. of South Australia (Australia)

679914 Nanosize particle movement in time-modulated nonuniform electric fields: a Fourier-Bessel series model [6799-43]

D. J. G. Bakewell, Univ. of Liverpool (United Kingdom)

679915 Finite element modelling of SAW correlator [6799-44]

A. C. Tikka, S. F. Al-Sarawi, D. Abbott, The Univ. of Adelaide (Australia)

679916 Estimation of atomic hydrophobicities using molecular dynamics simulation of peptides [6799-45]

M. Held, D. V. Nicolau, Liverpool Univ. (United Kingdom)

679917 Feature extraction of performance variables in elite half-pipe snowboarding using body mounted inertial sensors [6799-46]

J. W. Harding, Australian Institute of Sport (Australia), Griffith Univ. (Australia), and Olympic Winter Institute of Australia (Australia); J. W. Small, Griffith Univ. (Australia); D. A. James, Griffith Univ. (Australia) and Queensland Academy of Sport (Australia)

\section{POSTER SESSION}

6799 1A Improved protein-adsorption resistance of digital microfluidic device via surface coating and structure modification [6799-51]

S.-Y. Chen, H.-C. Hu, C.-S. YU, Y.-C. Hu, National Applied Research Labs. (Taiwan)

6799 1B Hydrogen gas sensor fabricated from polyanisidine nanofibers deposited on $36^{\circ} \mathrm{YX} \mathrm{LiTaO}_{3}$ layered surface acoustic wave transducer [6799-52]

L. Al-Mashat, RMIT Univ. (Australia); H. D. Tran, Univ. of California, Los Angeles (USA); W. Wlodarski, RMIT Univ. (Australia); R. B. Kaner, Univ. of California, Los Angeles (USA); K. Kalantar-zadeh, RMIT Univ. (Australia)

6799 1C Portable multi-immunosensing lab-on-a-chip (LOC) triggered by air bladder [6799-53] T. H. Kang, S. W. Park, J. H. Lee, H. C. Yoon, S. S. Yang, Ajou Univ. (South Korea) 
6799 1D Enhancement of reverse transfection efficiency by combining stimulated DNA surface desorption and electroporation [6799-54]

R. Creasey, Flinders Univ. (Australia); A. Hook, Flinders Univ. (Australia) and CSIRO Molecular and Health Technology (Australia); H. Thissen, Flinders Univ. (Australia), CSIRO Food Futures Flagship (Australia), and CSIRO Molecular and Health Technology (Australia);

N. H. Voelcker, Flinders Univ. (Australia) and CSIRO Food Futures Flagship (Australia)

$6799 \mathrm{IE} \quad$ Toward quality control of food using terahertz [6799-55]

B. S.-Y. Ung, B. M. Fischer, B. W.-H. Ng, D. Abbott, The Univ. of Adelaide (Australia)

$6799 \mathrm{IF}$ Simple micropatterning of proteins using polyelectrolyte multilayers and microcontact printing [6799-57]

J.-H. Lee, C.-H. Choi, C.-S. Lee, Chungnam National Univ. (South Korea)

$67991 \mathrm{H}$ Effect of dispersing nano-materials into structural adhesive on the electrical and mechanical properties [6799-59]

A. Chinnabhandar, H. N. Narasimha Murthy, M. Krishna, R.V. College of Engineering (India)

Author Index 
Downloaded From: https://www.spiedigitallibrary.org/conference-proceedings-of-spie on 26 Apr 2023

Terms of Use: https://www.spiedigitallibrary.org/terms-of-use 


\title{
Conference Committee
}

\author{
Symposium Chairs
}

Tiziana Di Matteo, The Australian National University (Australia)

Vijay K. Varadan, University of Arkansas (USA)

Conference Chair

Dan V. Nicolau, Monash University (Australia) and The University of Liverpool (United Kingdom)

\section{Conference Cochairs}

Derek Abbott, The University of Adelaide (Australia)

Kourosh Kalantar-Zadeh, Royal Melbourne Institute of Technology (Australia)

Tiziana Di Matteo, The Australian National University (Australia)

Sergey M. Bezrukov, National Institutes of Health (USA)

Program Committee

Maan M. Alkaisi, University of Canterbury (New Zealand) and MacDiarmid Institute for Advanced Materials and Nanotechnology (New Zealand)

John M. Bell, Queensland University of Technology (Australia)

Abdesselam S. Bouzerdoum, University of Wollongong (Australia)

Paul L. Burn, The University of Queensland (United Kingdom)

Kevin Burrage, University of Queensland (Australia)

Guido Caldarelli, Università degli Studi di Roma, La Sapienza (Italy)

Dante R. Chialvo, University of California, Los Angeles (USA)

Shin-Ho Chung, The Australian National University (Australia)

Christopher Colby, The University of Adelaide (Australia)

Peter J. Coloe, Royal Melbourne Institute of Technology (Australia)

Justin J. Cooper-White, The University of Queensland (Australia)

Liming Dai, University of Dayton (USA)

Paul C. W. Davies, Arizona State University (USA)

Stefan Diez, Max Planck Institute of Molecular Cell Biology and Genetics (Germany)

Calum Drummond, Commonwealth Scientific and Industrial Research Organisation (Australia)

William Ducker, The University of Melbourne (Australia)

Bernd $\mathbf{M}$. Fischer, The University of Adelaide (Australia)

Luigi Fortuna, Università degli Studi di Catania (Italy)

Nicolas H. Franceschini, Université de la Méditerranée (France) 
Hans Frauenfelder, Los Alamos National Laboratory (USA)

Vernonica Glattauer, Commonwealth Scientific and Industrial

Research Organisation (Australia)

John J. Gooding, University of New South Wales (Australia)

Min Gu, Swinburne University of Technology (Australia)

Armagan Kocer, BiOMaDe Technology Foundation (Netherlands)

Abraham P. Lee, University of California, Irvine (USA)

Hans Loeschner, IMS Nanofabrication AG (Austria)

Ted Maddess, The Australian National University (Australia)

David Mainwaring, Royal Melbourne Institute of Technology (Australia)

Peter Majewski, University of South Australia (Australia)

Ajay P. Malshe, University of Arkansas (USA)

Alf Mansson, Högskolan I Kalmar (Sweden)

Mark D. McDonnell, The University of Adelaide (Australia)

Ross McKinnon, University of South Australia (Australia)

Yos S. Morsi, Swinburne University of Technology (Australia)

Paul Mulvaney, The University of Melbourne (Australia)

Nicanor I. Moldovan, The Ohio State University (USA)

Uwe R. Muller, Nanosphere, Inc. (USA)

Mario Nicodemi, Università degli Studi di Napoli Federico II (Italy)

David C. O'Carroll, The University of Adelaide (Australia)

Ronald J. Pace, The Australian National University (Australia)

Petra Rudolf, University of Groningen (Belgium)

David Saint, The University of Adelaide (Australia)

Joe G. Shapter, Flinders University (Australia)

William B. Spillman, Jr., NanoSonic, Inc. (USA) and Virginia Polytechnic Institute and State University (USA)

Takahisa Taguchi, National Institute of Advanced Industrial Science and Technology (Japan)

Nicolas H. Voelcker, Flinders University (Australia)

Wojtek B. Wlodarski, Royal Melbourne Institute of Technology

(Australia)

Session Chairs

$1 \quad$ Nanoscale Interactions and Devices I

Dan V. Nicolau, Monash University (Australia) and The University of Liverpool (United Kingdom)

2 Nanoscale Interactions and Devices II

David J. G. Bakewell, The University of Liverpool (United Kingdom)

$3 \quad$ Nanoscale Interactions and Devices III

Dan V. Nicolau, Monash University (Australia) and The University of Liverpool (United Kingdom) 
4 BioMEMS, Biosensors, and Microfluids I

Dan V. Nicolau, Monash University (Australia) and The University of Liverpool (United Kingdom)

5 BioMEMS, Biosensors, and Microfluids II

Dan V. Nicolau, Monash University (Australia) and The University of Liverpool (United Kingdom)

6 BioMEMS, Biosensors, and Microfluids III

Dan V. Nicolau, Monash University (Australia) and The University of Liverpool (United Kingdom)

7 BioMEMS, Biosensors, and Microfluids IV

David J. G. Bakewell, The University of Liverpool (United Kingdom)

$8 \quad$ Modelling and THZ Technology

Dan V. Nicolau, Monash University (Australia) and The University of Liverpool (United Kingdom) 
Downloaded From: https://www.spiedigitallibrary.org/conference-proceedings-of-spie on 26 Apr 2023

Terms of Use: https://www.spiedigitallibrary.org/terms-of-use 


\section{Introduction}

This conference on BioMEMS and Nanotechnology III is part of the SPIE 2007 Symposium on Microelectronics, MEMS, and Nanotechnology held at The Manning Clark Centre, Australian National University (ANU), Canberra, 4-7 December, 2007. Four other parallel conferences were held as part of this symposium: Microelectronics: Design, Technology, \& Packaging; Device \& Process Technologies for Microelectronics; MEMS, Photonics, \& Nanotechnology, and Complex Systems.

The papers in these proceedings represent some of the latest advances in microand nano-engineering applications in the biomedical arena, as well as nanotechnology. The contributed manuscripts have been peer reviewed by the international conference committee of the conference.

A big thanks to the symposium Chairs, Tiziana Di Matteo (Australian National University) and Vijay K. Varadan (University of Arkansas) for their splendid work; and special thanks to our Program Committee for their support.

Finally, our appreciation must go to the authors for sharing their work, the attendees for their stimulating questions, and both the authors and attendees for their enthusiasm. The resulting interaction made this a most productive and enjoyable conference.

Dan V. Nicolau

Sergey M. Bezrukov

Kourosh Kalantar-Zadeh

Tiziana Di Matteo

Derek Abbott 
Downloaded From: https://www.spiedigitallibrary.org/conference-proceedings-of-spie on 26 Apr 2023

Terms of Use: https://www.spiedigitallibrary.org/terms-of-use 
Cosponsored by:
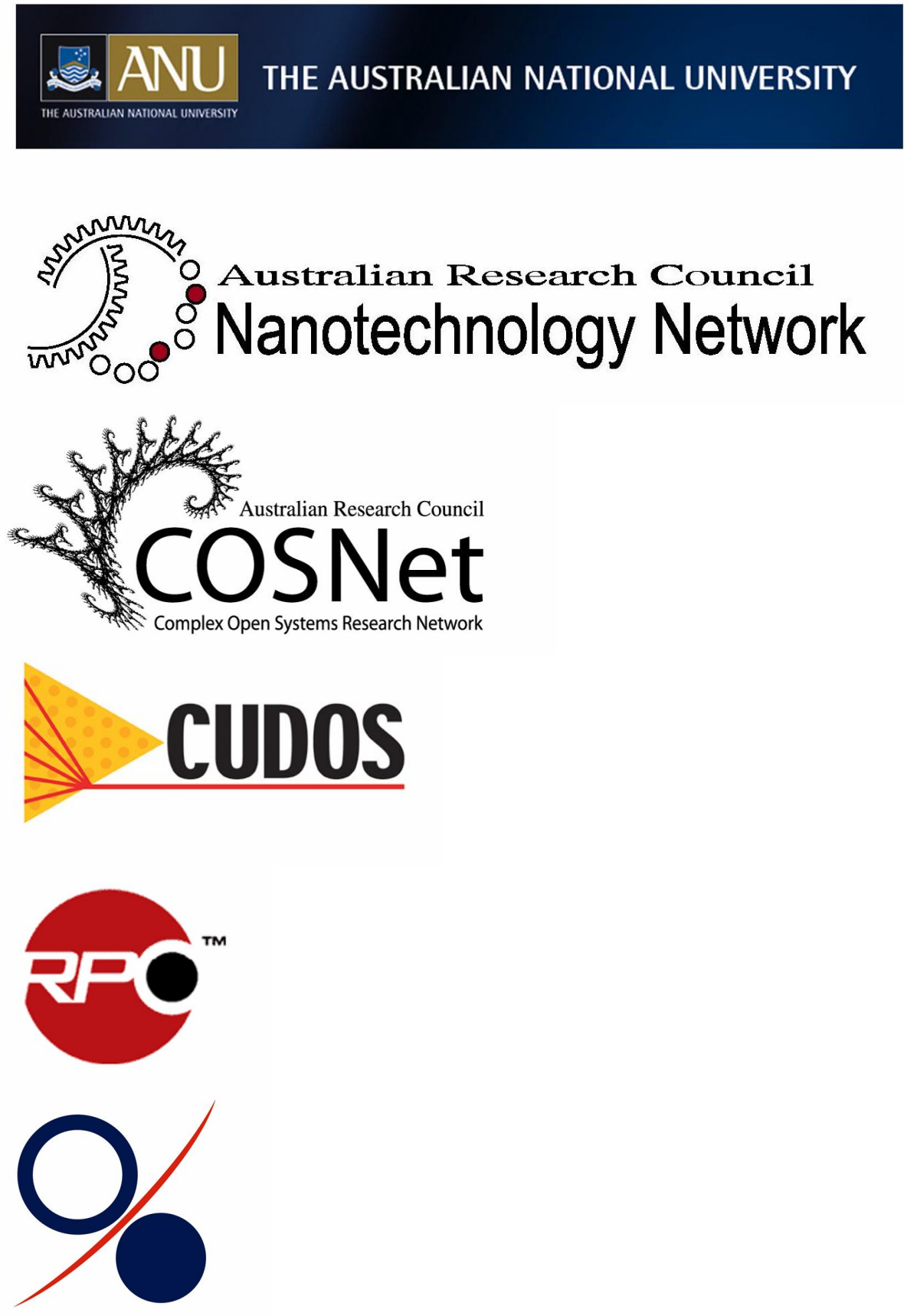

BANDWIDTH FOUNDRY 
Downloaded From: https://www.spiedigitallibrary.org/conference-proceedings-of-spie on 26 Apr 2023

Terms of Use: https://www.spiedigitallibrary.org/terms-of-use 